Article

\title{
Screening and Comparative Characterization of Microorganisms from Iranian Soil Samples Showing $\omega$-Transaminase Activity toward a Plethora of Substrates
}

\author{
Najme Gord Noshahri ${ }^{1}{ }^{(\mathbb{D}}$, Jamshid Fooladi ${ }^{1, *}$, Christoph Syldatk ${ }^{2}$, Ulrike Engel ${ }^{2}$, \\ Majid M. Heravi ${ }^{3}$, Mohammad Zare Mehrjerdi ${ }^{4}$ and Jens Rudat ${ }^{2, *(D)}$ \\ 1 Department of Biotechnology, Faculty of Biology Science, Alzahra University, 1993893973 Tehran, Iran \\ 2 BLT_II: Technical Biology, Karlsruhe Institute of Technology (KIT), Fritz-Haber-Weg 4, 76131 Karlsruhe, \\ Germany; christoph.syldatk@kit.edu (C.S.); ulrike.engel@kit.edu (U.E.) \\ 3 Department of Chemistry, School of Sciences, Alzahra University, 1993891176 Tehran, Iran; \\ mmheravi@alzahra.ac.ir \\ 4 Higher Education Complex of Shirvan, 9468194477 Shirvan, Iran; mzarem@um.ac.ir \\ * Correspondence: jfooladi@alzahra.ac.ir (J.F.); jens.rudat@kit.edu (J.R.); Tel.: +98-21-880-440-40 (J.F.); \\ +49-721-608-484-28 (J.R.)
}

Received: 26 September 2019; Accepted: 18 October 2019; Published: 22 October 2019

\begin{abstract}
In this study, soil microorganisms from Iran were screened for $\omega$-transaminase ( $\omega$-TA) activity based on growth on minimal media containing (rac)- $\alpha$-methylbenzylamine (rac- $\alpha$-MBA) as a sole nitrogen source. Then, for the selection of strains with high enzyme activity, a colorimetric o-xylylendiamine assay was conducted. The most promising strains were identified by $16 \mathrm{~S}$ rDNA sequencing. Five microorganisms showing high $\omega$-TA activity were subjected to determine optimal conditions for $\omega$-TA activity, including $\mathrm{pH}$, temperature, co-solvent, and the specificity of the $\omega$-TA toward different amine donors and acceptors. Among the five screened microorganisms, Bacillus halotolerans turned out to be the most promising strain: Its cell-free extract showed a highly versatile amino donor spectrum toward aliphatic, aromatic chiral amines and a broad range of $\mathrm{pH}$ activity. Transaminase activity also exhibited excellent solvent tolerance, with maximum turnover in the presence of $30 \%(v / v)$ DMSO.
\end{abstract}

Keywords: $\omega$-transaminase; $\alpha$-methylbenzylamine; biocatalysis; chiral amine; biotransformation

\section{Introduction}

Chiral amines as building blocks are prevalent in pharmaceuticals and chemical industries [1]. For instance, chiral amines are present in roughly $40 \%$ of FDA approved pharmaceuticals $[2,3]$. Furthermore, chiral $\beta$-amino acids ( $\beta$-aas) have attracted significant attention recently [4]. They are critical building blocks in highly important medicines and natural compounds such as maraviroc (HIV remedy) [5,6], taxol (cytostatic drug against breast and ovarian cancer), jaspamide (insecticidal and antifungal agent), theopalauamide (antifungal compound), and dolastatin (antitumor agent) [7]. $\beta$-aas are also employed in the production of peptidomimetics that are stable against degradation by proteolytic enzymes $[4,8]$.

The significant challenge in industry is to use optically pure amines and amino acids from cost-effective production [1,9]. For the mass production of such compounds, nowadays biocatalysts are frequently used to comply with green chemistry as well be economically feasible $[1,5]$. Among various enzymatic methods for producing chiral amine compounds, $\omega$-transaminases 
( $\omega$-TAs) are promising enzymes to synthesize chiral amines. They show high substrate spectra, enantioselectivity, and no requirement to regenerate external cofactors [10-13]. They belong to pyridoxal-5' -phosphate-(PLP)-dependent enzymes that transfer an amino group from an amino donor to amino accepters such as prochiral ketones or aldehydes [14,15]. In addition, $\omega$-TAs can be used for providing optically enriched chiral amino acids via the kinetic resolution of racemic amines or asymmetric synthesis from prochiral ketones [12].

A restricted substrate scope for large molecules [16], as well as rather low enzyme stability under extreme reaction conditions associated with $\mathrm{pH}$, temperature [17], and organic solvents $[5,13]$ have been major hurdles of using $\omega$-TAs. Thus, these limitations should be circumvented by additional screening approaches to fill the toolbox of industrially applicable enzymes.

Basically, there are different approaches to discover new $\omega$-TAs: metagenomic screenings $[18,19]$, site-directed mutagenesis of well-established enzymes [20], and screening new biocatalysts by identifying novel microorganisms from as-yet unexplored screening sites [21-23].

Results of several studies indicated that Iranian landscapes contain highly diverse microbial storages due to considerable variety in geographical features, including mountain range peaks with volcano activity, sandy deserts (Dasht-e Lut is one of the hottest points of the Earth), rivers [24], forest areas, hot springs, glaciers, and frequent snowing. Iran also has two coastlines to its north and south. Besides the extremely versatile environments in Iran, industries such as petroleum (oil well) and petrochemical units releasing chemical substances cause influences on the microorganism populations of the above-mentioned country. With such a variety of environments, Iran's soil can be considered a rich source for screening microorganisms, which are able to produce special extremophile biocatalysts [25-28].

The purpose of this study is to identify novel $\omega$-TA from Iranian soil microorganisms to be examined as a catalyst in the synthesis of enantiopure $\beta$-amino acid ( $\beta$-aa) and other chiral amino compounds. Relevant properties of this novel $\omega$-TA, such as the effect of temperature, $\mathrm{pH}$, and solvent and substrate spectra were also investigated.

\section{Results and Discussion}

\subsection{Microorganisms Screening and Identification}

In this study, 42 strains were isolated by enrichment culture against (rac)- $\alpha$-methylbenzylamine (rac-MBA) as a sole nitrogen source. Induction and amount of $\omega$-TA is affected by nitrogen source in media. In complex media such as Luria-Bertani (LB) medium, some of the microorganisms produce enzymes with lower activity [29]. Therefore, minimal media (MIM) containing (rac)- $\alpha$-MBA as a model amine compound $[22,23]$ was used in the experiment.

They were subsequently validated through $o$-xylylenediamine (o-XDA) assay, with the color changing from yellow to black after $4 \mathrm{~h} . o$-XDA after deamination undergoes spontaneous cyclization, tautomerization, and irreversible polymerization to form a black product [1]. Five strains showing $\omega$-TA activity were found to be promising. Four of these strains were identified by $16 \mathrm{~S}$ rDNA sequencing to be members of the genus Bacillus close to Bacillus halotolerans $(\mathrm{BaH})(99.93 \%$ similarity) and Bacillus endophyticus (BaE) (99.76\% similarity). Two subspecies belong to Bacillus subtilis with 99.92\% and $99.93 \%$ similarity to stercoris (BaS) and inaquosorum (BaI), respectively. The fifth bacterium is associated to Rhizobium radiobacter (RhZ) with $99.77 \%$ similarity (Table 1). All of the strains except $\mathrm{BaE}$ were isolated from first method of screening. 
Table 1. Results of 16SrDNA sequencing.

\begin{tabular}{ccc}
\hline Isolate & Closest Relative in GenBank & \% Similarity/Sequence Length (bp) \\
\hline $\mathrm{BaH}$ & $\begin{array}{c}\text { Bacillus halotolerans } \\
\text { (LPVF01000003) }\end{array}$ & $99.9 / 1388$ \\
\hline $\mathrm{BaE}$ & Bacillus endophyticus (AF295302) & $99.7 / 1273$ \\
\hline $\mathrm{BaS}$ & $\begin{array}{c}\text { Bacillus subtilis subsp. stercoris } \\
\text { (JHCA01000027) }\end{array}$ & $99 / 1385$ \\
\hline $\mathrm{BaI}$ & $\begin{array}{c}\text { Bacillus subtilis subsp. inaquosorum } \\
\text { (AMXN01000021) }\end{array}$ & $99.9 / 1406$ \\
\hline $\mathrm{RhZ}$ & Rhizobium radiobacter (AJ389904) & $99.4 / 1338$ \\
\hline
\end{tabular}

\subsection{Enzymatic Properties and Substrate Specificity}

Appropriate temperature, $\mathrm{pH}$, and organic solvents play important roles in $\omega$-TA activity $[5,30]$. To survey such effects, the optimum reaction condition against these three factors as investigated in the screened bacteria. Several studies have been performed by applying cell and crude extract to convert different substrates $[2,18,21,29,31-33]$, so instead of using high-priced purified protein, we applied cell-free extracts to optimize reaction parameters and to investigate substrate scope.

The relative values of $\omega$-TA activity were calculated based on producing acetophenone as a product of (S)-MBA deamination. The highest activity was considered as $100 \%$.

\subsubsection{Effect of Temperature on $\omega$-TA Activity}

The cell-free extracts were incubated at defined temperatures $\left(25-65^{\circ} \mathrm{C}\right)$ for one hour. The crude extracts of $\mathrm{BaH}, \mathrm{RhZ}$, and $\mathrm{BaS}$ shared similar expected mesophilic temperature profiles between 30 and $65^{\circ} \mathrm{C}$, with highest activity at $35^{\circ} \mathrm{C}$, which is reported for other $\omega$-TAs [21,34]. They exhibited reasonable activity of around $70 \%$ up to $45^{\circ} \mathrm{C}$. Among all of them, $40-50 \%$ of activity remained at $50{ }^{\circ} \mathrm{C}$, which decreased to approximately $10-20 \%$ at temperatures above $60^{\circ} \mathrm{C}$ (Figure 1a).

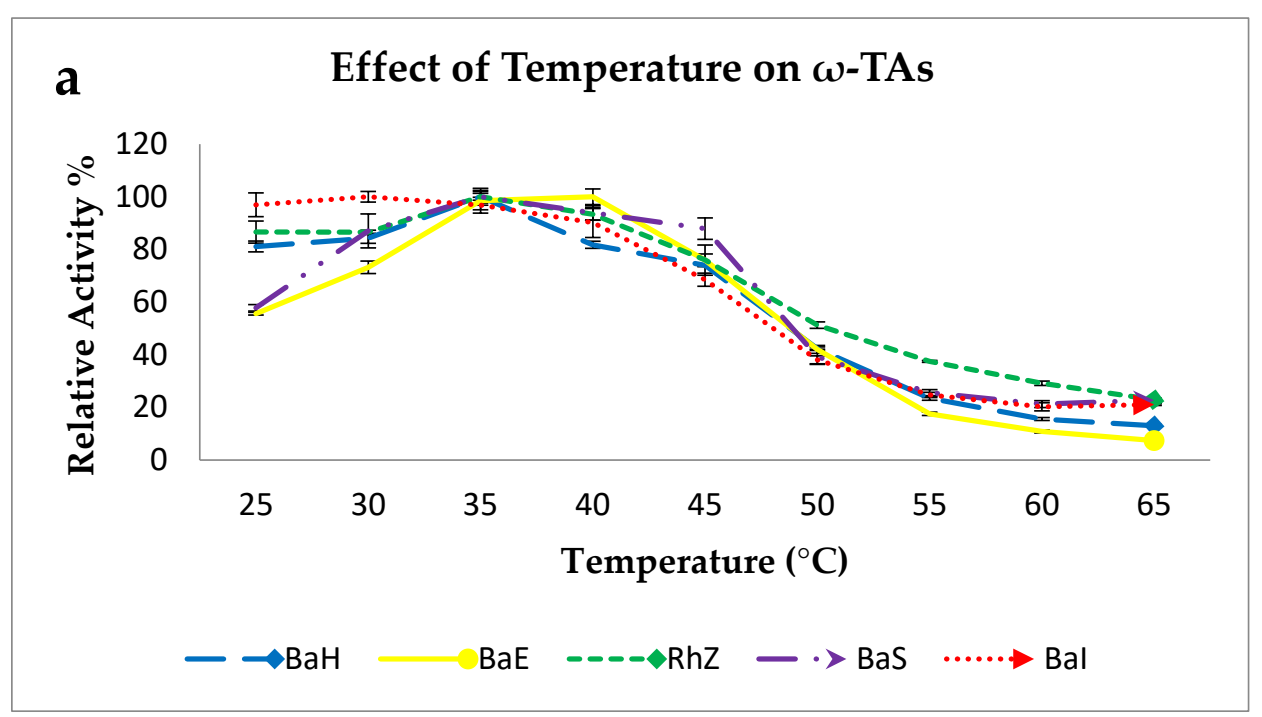

Figure 1. Cont. 


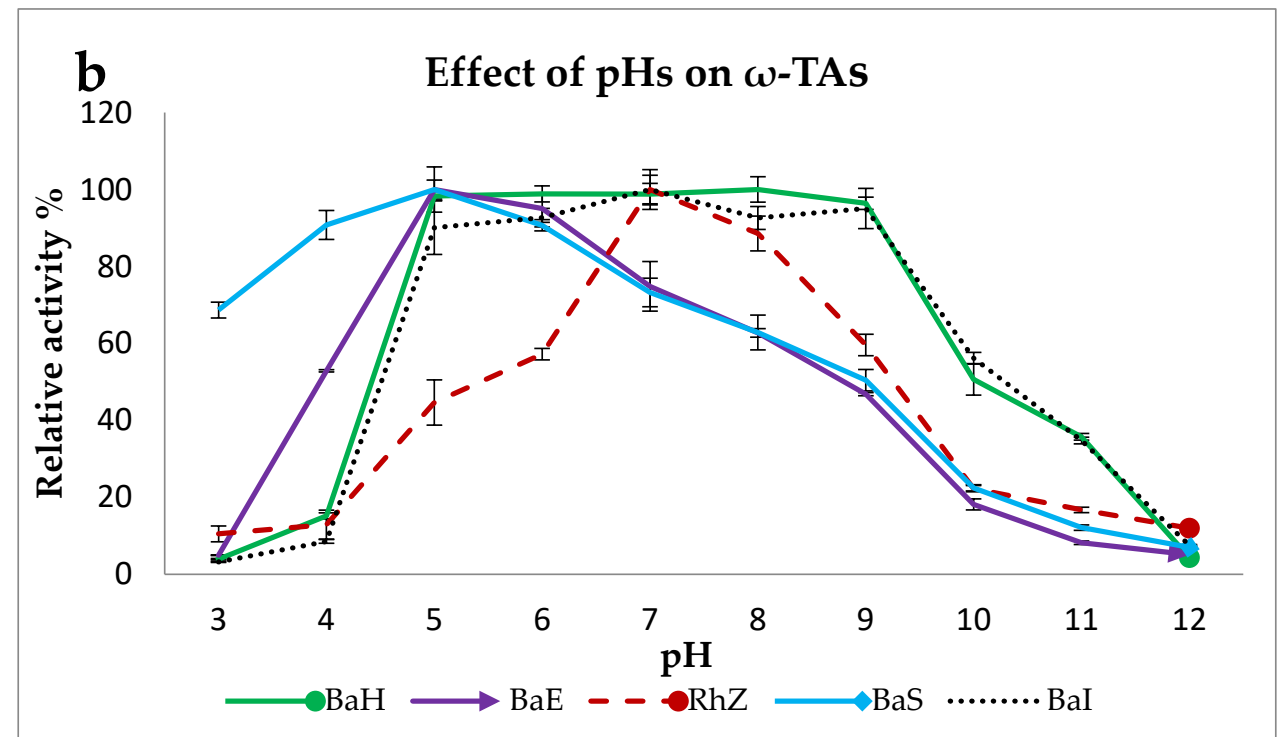

Figure 1. The effect of temperature (a) and $\mathrm{pH}(\mathbf{b})$ on the amination of pyruvate and (S)-MBA as amino donor using $1 \mathrm{mg} / \mathrm{mL}$ of cell-free extracts of screened strains: Bacillus halotolerans $(\mathrm{BaH})$, Bacillus endophyticus (BaE), Rhizobium radiobacter (RhZ), Bacillus subtilis subsp. stercoris (BaS) and Bacillus subtilis subsp. inaquosorum (BaI).Reaction conditions are given in the method section. Formation of acetophenone was detected by HPLC at $254 \mathrm{~nm}$. The value of $100 \%$ corresponded to the highest activity. Error bars represent \pm standard deviation.

For $\omega$-TABaE and $\omega$-TABaI, the optimum reaction temperature was $40^{\circ} \mathrm{C}$ and $30^{\circ} \mathrm{C}$, respectively. No significant change of activity was observed at $35^{\circ} \mathrm{C}$. Thus, for surveying the effect of $\mathrm{pH}$ and solvent on enzyme activity on all crude extracts, the temperature was maintained at $35^{\circ} \mathrm{C}$. Additionally, $\omega$-TABaI showed approximately the same activity at temperatures between 20 and $30^{\circ} \mathrm{C}$ (Table S1).

\subsubsection{Effect of $\mathrm{pH}$ on $\omega$-TA Activity}

In contrast to other $\omega$-TAs that usually show their maximum activity at slightly alkaline $\mathrm{pH}[12,21,31], \omega$-TABaI and $\omega$-TABaH exhibited an almost constant activity in the $\mathrm{pH}$ range of 5 to 9 . Surprisingly, for $\omega$-TABaS and $\omega$-TABaE, the highest enzyme activity was observed under acidic conditions ( $\mathrm{pH} 5$ ). Notably, $70 \%$ of $\omega$-TABaS activity remained at $\mathrm{pH} 3$, Furthermore, $\omega$-TARhz preferred neutral conditions (Figure $1 \mathrm{~b}$ ). No enzyme activity was observed at $\mathrm{pH} 12$. In the literature data, there is no report concerning $\omega$-TA activity in acidic conditions. $\omega$-TA activity at different $\mathrm{pHs}$ was mostly tested in $\mathrm{pH}$ range from 6 to $11[4,17,18]$.

\subsubsection{Effect of Organic Solvents on $\omega$-TA Activity}

Organic solvents are often added to $\omega$-TA reactions to increase substrate solubility. However, this mostly causes negative effects on enzyme activity [10]. Therefore, the examination of the tolerance of the applied enzyme to different solvents is highly required [5]. To analyze whether solvents affect enzyme activity, four different solvents with a $0 \%-20 \%$ with the exception of DMSO which increased up to $40 \% v / v$ concentration were tested. The $\omega$-TA activity in aqueous buffer without addition of organic solvents was set as $100 \%$. The results were expressed as relative activity in $\%$.

Dimethyl sulfoxide (DMSO) is a common solvent that was used in concentrations ranging from $5 \%-20 \% v / v$ in different projects [5]. DMSO as co-solvent led to the highest activity, followed by methanol, N,N-Dimethylformamide (DMF), and isopropanol. In some cases (BaI and Rhz), the reactions without any co-solvent showed better activity than methanol. It is remarkable to mention that $\omega$-TABaH activity was enhanced threefold with a concentration of DMSO up to $30 \%$. The results again suggest that DMSO is the most suitable organic solvent for catalytic activation of $\omega$-TAs. However, 
methanol in some cases also increased enzyme activity (Figure 2). Methanol was mentioned as a second co-solvent after DMSO for enhancing $\omega$-TA activity in Pawer et al.'s experiment [2].

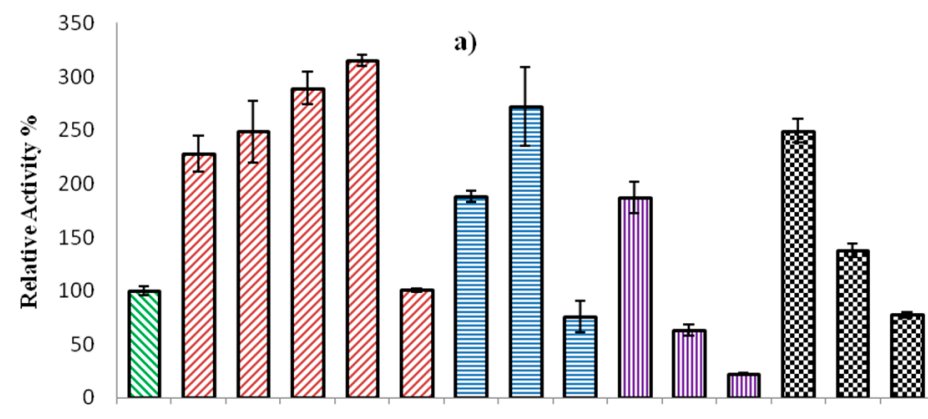

$$
200
$$

b)
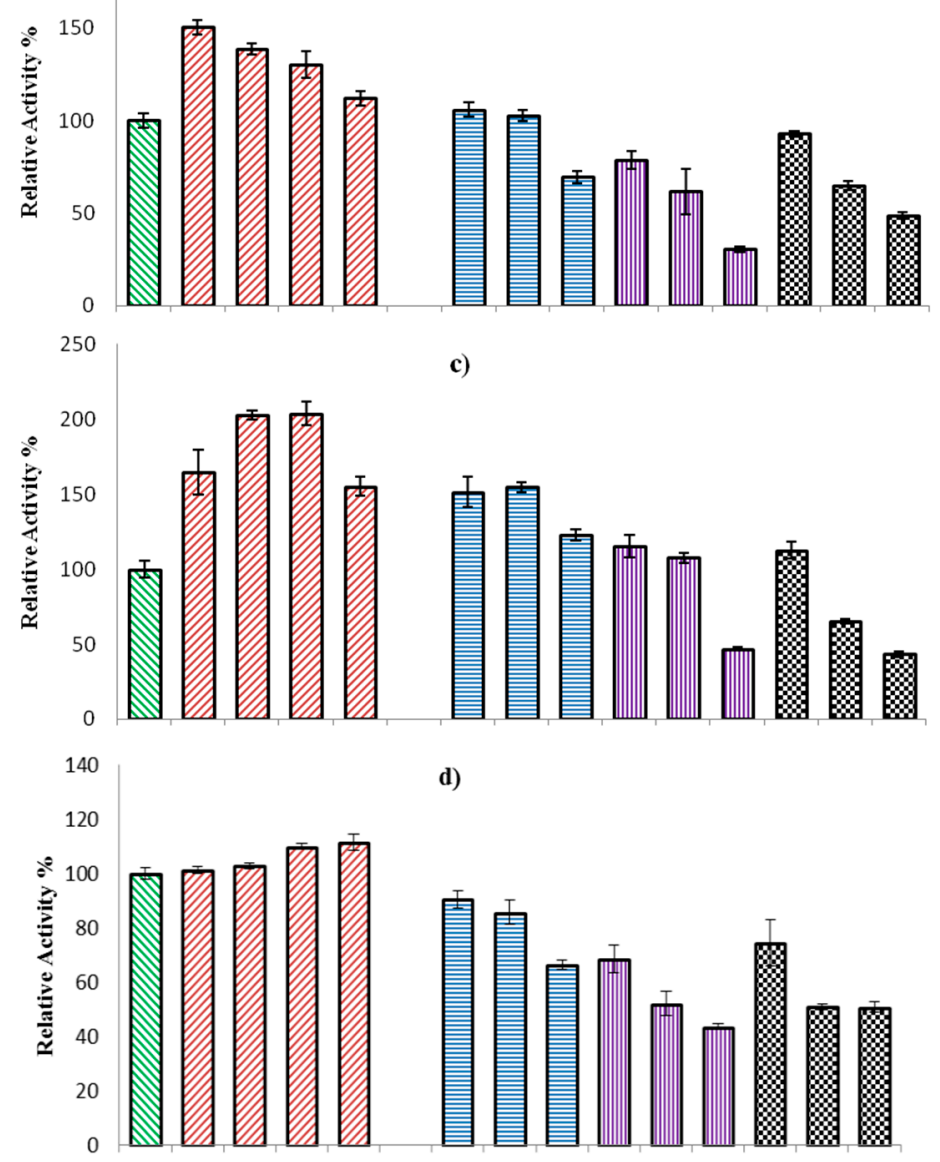

Figure 2. Cont. 


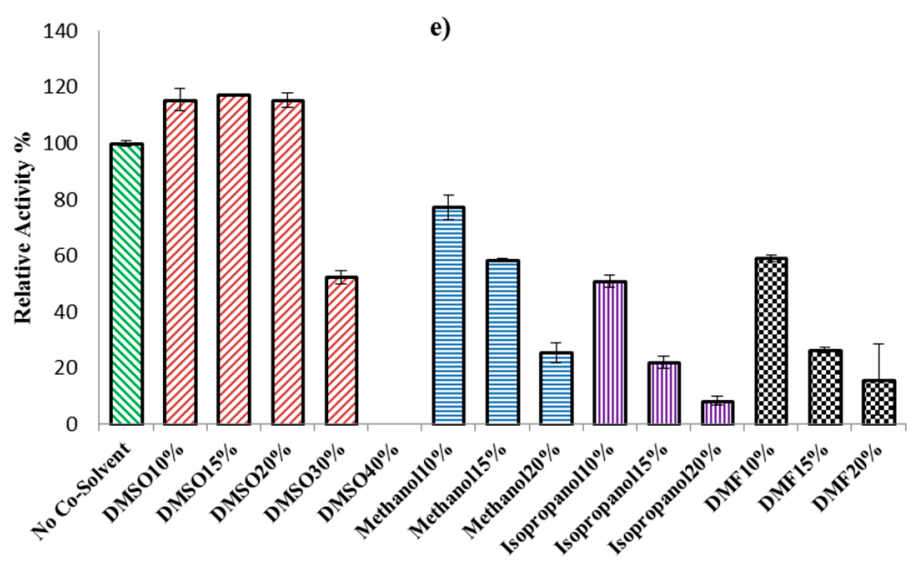

Figure 2. Effect of co-solvent on $\omega$-TA activity of screened strains. (a) BaH; (b) BaE; (c) BaS; (d) RhZ; (e) BaI. The value of $100 \%$ corresponds to enzyme activity in the no co-solvent condition. $1 \mathrm{mg} / \mathrm{mL}$ cell-free extract was added to react under the following conditions: (S)-MBA $(10 \mathrm{mM})$, pyruvate $(10 \mathrm{mM})$, PLP $(0.1 \mathrm{mM})$, and co-solvent $(0-30 \% v / v)$ in Britton-Robinson buffer $(\mathrm{pH} 7)$ at $35^{\circ} \mathrm{C}$. Formation of acetophenone was detected by HPLC at $254 \mathrm{~nm}$. Error bars represent \pm standard deviation.

\subsubsection{Substrate Specificity and Enantioselectivity}

The substrate spectrum of all strains was investigated in order to find the most suitable amino donor and acceptor.

Regarding amino donors, 28 substrates, including aliphatic and aromatic amino compounds were reacted to pyruvate as an amino acceptor to investigate amino donor specificity, and alanine generation was monitored by the HPLC technique. Racemates as well as the pure, $(S)$ and $(R)$ enantiomers (if available) of amino donors were chosen to explore the enantioselectivity of $\omega$-TA. The results of the substrate screening are illustrated in Table 2. HPLC analysis proved that all enzymes show predominant formation of an (S)-configuration. This is in accordance with most previously reported publications in the literature indicating that $(R)$-stereoselectivity are rather rare in wild-type microorganisms [35]. All cell-free extracts showed high activity against (S)- $\alpha$-methylbenzylamine (S-MBA) 1s.

$\mathrm{BaH}$ showed considerable activity toward a wide range of substrates, including $(S),(R)$, and racemates of aromatic and aliphatic amino donors. Although this cell-free extract also showed activity toward some tested ( $R$ )-enantiomers (1r, 2r, 4r, 5r, 7r, 8r, 13r), (S)-selectivity appeared to be not so strict in this strain. Notably, it is difficult to conclude that BaH showed $(R)$-selectivity since in this study, crude extract was applied. There is a possibility that $(R)$ converted to $(S)$-enantiomer via enzymatic racemization [36], and then the latter was subjected to $\omega$-TA activity. On the other hand, $(R)$-preference towards $13 \mathrm{r}$ in compare to $13 \mathrm{~s}$ leads to another hypothesis, in which both $\mathrm{R}$ and $\mathrm{S}$ transaminases are present in crude extract.

While the cell-free extract of $\mathrm{BaH}$ revealed varying enantiopreference toward all tested amino donors to different degrees, the substrate specificity was found to resemble what has previously been reported by Mathew et al. [5,30], as a preference to react with aromatic $\beta$-amino acids is clearly visible [5]. (S)-MBA 1s is converted with the highest activity, which therefore was set as $100 \%$. Although a few $\omega$-TAs are described with activity toward aromatic $\beta$-amino acids (56), it is remarkable that $\mathrm{BaH}$ uses $\beta$-phenylalanine $(\mathbf{1 3}, \mathbf{1 3 s}, \mathbf{1 3 r})$ and (rac)- $\beta$-homophenylalanine (14) as an amino donor; both of these were inert for crude extraction from other bacteria in this experiment, which implies the presence of a broad binding pocket in the active site of $\omega$-TABaH. $\omega$-TA activity against $\mathbf{1 4}$ has been reported by Mathew et al. for $\omega$-TABG, with $50 \%$ relative activity in comparison with 13 [30]. A recent study by Buß et al. explained the lack of $\omega$-TA activity against 14 (by an $\omega$-TA that was highly active against 13) by sterice hindrance caused by the additional carbon atom located between the amino group and phenyl group [36]. Several substituted derivatives of $\beta$-phenylalanine are converted as well. 
Table 2. Amino donor screened assays were carried out in Britton-Robinson buffer, $\mathrm{pH} 7$ with amino donor $(10 \mathrm{mM})$, pyruvate $(10 \mathrm{mM})$, PLP $(0.1 \mathrm{mM})$, and 15\% $(v / v)$ DMSO. The reaction was initiated by adding crude extract to a final concentration of $1 \mathrm{mg}$ protein per $\mathrm{ml}$. Reactions were performed at $35^{\circ} \mathrm{C}, 600 \mathrm{rpm}$ for $20 \mathrm{~h}$. Relative activity was measured by HPLC detection of alanine formation at $338 \mathrm{~nm}$. All reactions were conducted in triplicate, and each cell-free extract was separately analyzed for alanine content as a control.

\begin{tabular}{|c|c|c|c|c|c|c|}
\hline & \multirow{2}{*}{ Amino Donor } & \multicolumn{5}{|c|}{ Relative Activity\% } \\
\hline & & BaH & $\mathrm{BaE}$ & BaS & BaI & RhZ \\
\hline $1 \quad$ (rac) & \multirow{3}{*}{$\alpha$-methylbenzylamine } & 53 & 48 & 45 & 60 & 36 \\
\hline 1s $\quad(S)$ & & 100 & 100 & 100 & 100 & 100 \\
\hline 1r $\quad(R)$ & & 23 & 0 & 0 & 6 & 0 \\
\hline $2 \quad(\mathrm{rac})$ & \multirow{3}{*}{ 3-amino-3-(4-chlorophenyl) propionic acid } & 19 & 0 & 0 & 0 & 0 \\
\hline $2 s \quad(S)$ & & 20 & 0 & 0 & 0 & 0 \\
\hline $2 \mathbf{r} \quad(R)$ & & 16 & 0 & 0 & 0 & 0 \\
\hline $3 \quad(\mathrm{rac})$ & 3-amino-3-(3,4-dichloro-phenyl)propionic acid & 20 & 0 & 0 & 0 & 0 \\
\hline $4 \quad(\mathrm{rac})$ & \multirow{2}{*}{ 3-amino-3-(4-nitrophenyl)propionic acid } & 51 & 0 & 0 & 0 & 0 \\
\hline $4 \mathbf{r} \quad(R)$ & & 19 & 0 & 0 & 0 & 0 \\
\hline $5 \mathbf{r} \quad(R)$ & (R)3-amino-3-(2-nitro-phenyl)-propionic acid & 16 & 0 & 0 & 0 & 0 \\
\hline $6 \quad(\mathrm{rac})$ & \multirow{2}{*}{ 3-amino-3-(4-methoxyphenyl) propionic acid } & 21 & 0 & 0 & 0 & 0 \\
\hline 6s $\quad(S)$ & & 17 & 0 & 0 & 0 & 0 \\
\hline $7 \mathrm{~s} \quad(S)$ & \multirow{2}{*}{ 3-amino-3-(4-hydroxy-phenyl)propionic acid } & 18 & 0 & 0 & 0 & 0 \\
\hline $7 \mathbf{r} \quad(R)$ & & 15 & 0 & 0 & 0 & 0 \\
\hline $8 \quad(\mathrm{rac})$ & \multirow{2}{*}{ 3-amino-3-(4-bromophenyl)-propionic acid } & 21 & 0 & 0 & 0 & 0 \\
\hline $8 \mathbf{r} \quad(R)$ & & 20 & 0 & 0 & 0 & 0 \\
\hline $9 \quad$ (rac) & \multirow{2}{*}{ 3-amino-3-(4-fluorophenyl)propionic acid } & 43 & 0 & 0 & 0 & 0 \\
\hline 9s $\quad(S)$ & & 16 & 0 & 0 & 0 & 0 \\
\hline $10(\mathrm{rac})$ & $\begin{array}{l}\text { Methyl(-3-amino-3-phenyl propanoate } \\
\text { hydrochloride) }\end{array}$ & 11 & 0 & 0 & 0 & 0 \\
\hline 11 (rac) & 3-amino-3-(4-isopropylphenyl) propionic acid & 20 & 0 & 0 & 0 & 0 \\
\hline 12 (rac) & 1-aminocyclopropane-1-carboxylic acid & 17 & 17 & 0 & 30 & 0 \\
\hline 13 (rac) & \multirow{3}{*}{$\beta$-phenylalanine } & 17 & 0 & 0 & 0 & 0 \\
\hline 13s $(S)$ & & 16 & 0 & 0 & 0 & 0 \\
\hline 13r $(R)$ & & 22 & 0 & 0 & 0 & 0 \\
\hline $14 \quad(r a c)$ & $\beta$-Homophenylalanine & 16 & 0 & 0 & 0 & 0 \\
\hline 15 & Isopropylamine & 20 & 0 & 0 & 21 & 0 \\
\hline 16 & Sec-butylamine & 25 & 7 & 0 & 27 & 0 \\
\hline 17s $(S)$ & 3-amino butyric acid & 91 & 59 & 54 & 20 & 135 \\
\hline
\end{tabular}

The activity against (S)-MBA was set as 100. An amount under 1\% was considered as zero activity. 
BaE presented only (S)-selectivity in relation to tested substrates. Similar to BaH, the strain's crude extract exhibited activity toward 1s, almost double that of $\mathbf{1}$. BaE and BaH share the same activity toward 12, while BaI showed almost double the activity in comparison with those. The relative activity of $\omega$-TA of BaI toward ( $\mathrm{rac}$ )-MBA 1 exceeded $60 \%$, which might be related to the presence of racemase in the crude extract of bacteria [37,38].

Crude extracts of RhZ and BaS displayed (S)-selectivity toward the tested amino donors with similar preference profiles. RhZ showed more activity toward $17 \mathrm{~s}$ as an aliphatic substrate than MBA 1s, which was not observed for other screened strains.

Amino acceptors play a critical role in $\omega$-TA activity [30]. Eight ketones were reacted with (S)-MBA to explore the amino acceptor specificities by HPLC detection of acetophenone production (Table 3). Aliphatic ketones such as sodium pyruvate $7 \mathbf{b}$ and $\alpha$-ketoglutaric acid $8 \mathbf{b}$ showed high conversion, whereas most aromatic ketones were not accepted by the investigated enzymes.

Table 3. Amino acceptor screened assays were carried out in Britton-Robinson buffer, $\mathrm{pH} 7$ with (S)-MBA (10 mM), amino acceptor (10 mM), PLP (0.1 mM), and 15\% (v/v) DMSO. The reaction was started by the addition of crude extract to a final concentration of $1 \mathrm{mg} / \mathrm{mL}$ in the following conditions: $35^{\circ} \mathrm{C}, 600 \mathrm{rpm}$ for $20 \mathrm{~h}$. Relative activity was measured by HPLC detection of acetophenone formation at $254 \mathrm{~nm}$. All reactions were conducted in triplicate, and each cell-free extract was separately analyzed as a control.

\begin{tabular}{|c|c|c|c|c|c|c|}
\hline \multirow{2}{*}{\multicolumn{2}{|c|}{ Amino Acceptors }} & \multicolumn{5}{|c|}{ Relative Activity\% } \\
\hline & & BaH & $\mathrm{BaE}$ & BaS & BaI & RhZ \\
\hline $1 b$ & Ethyl benzoylacetate & 40.95 & 0 & 20.84 & 14.87 & 0 \\
\hline $2 b$ & $\begin{array}{c}\text { Ethyl } \\
\text { 3-(4-methoxyphenyl)-3-oxopropanoate }\end{array}$ & 0 & 0 & 0 & 60.48 & 0 \\
\hline $3 b$ & Sodium 3-oxo-3-phenylpropanoate & 0 & 0 & 0 & 0 & 0 \\
\hline $4 b$ & Ethyl(4-flurobenzoyl)acetate & 0 & 0 & 0 & 0 & 0 \\
\hline $5 b$ & Ethyl(4-chlorobenzoyl)acetate & 0 & 0 & 0 & 0 & 0 \\
\hline $6 b$ & Ethyl 4-nitrobenzoylacetate & 0 & 0 & 0 & 0 & 0 \\
\hline $7 \mathrm{~b}$ & Pyruvate & 100 & 100 & 43.73 & 100 & 36.39 \\
\hline $8 b$ & $\alpha$-ketoglutarate & 17.09 & 7.31 & 100 & 0 & 100 \\
\hline
\end{tabular}

In each column, the highest activity was defined as $100 \%$. Activity less than $1 \%$ was considered zero.

Cell-free extract of $\mathrm{BaH}, \mathrm{BaS}$, and $\mathrm{BaI}$ exhibited some activity toward bulkier substrates, including $\mathbf{1} \mathbf{b}$ or $\mathbf{2} \mathbf{b}$. It is supposed that $\beta$-amino acid esters were produced by using these acceptors, but this needs to be investigated in further experiments. $\mathrm{BaH}, \mathrm{BaS}$, and BaI showed activity toward $\mathbf{1} \mathbf{b}$ as amino acceptor. BaI was the only extract to show activity toward acceptor $\mathbf{2} \mathbf{b}$.

The substrate scope of $\omega$-TA is determined by the active site, which consists of a large and a small binding pocket. The former can accommodate bulky residues, including aryl groups, whereas the latter is loaded by a small group such as a methyl substituent [14]. So most $\omega$-TAs have a limitation in accepting bulky substrates without applying protein engineering. Voss et al. reported that after double mutation on $\omega$-TA 3FCR from Ruegeria sp. TM1040, this enzyme gained activity toward bulkier substrates such as phenylpropylamine and phenylbutylamine [16]. Strain $\mathrm{BaH}$ showed a good 
ability to convert bulky substrates and showed different substrate spectra with known $\omega$-TAs $[15,35]$. Purification and further investigation of this enzyme is intended for further studies.

\section{Materials and Methods}

\subsection{Chemicals}

All solvents and chemicals used in this study were purchased from Sigma-Aldrich (St Louis, MO, USA), Carl Roth GmbH (Karlsruhe, Germany), and Peptech (Burlington, MA, USA).

\subsection{Screening and Identification}

\subsubsection{Enrichment of Microorganisms on (rac)- $\alpha$-MBA as Sole Nitrogen Source}

Due to the role of transaminase in nitrogen metabolism [29], areas enriched with nitrogen compounds were chosen as potential sites for screening novel $\omega$-transaminase. Soil samples $(2 \mathrm{~g})$ from a petrochemical site, oil well, and an agriculture field in Iran were separately suspended in $200 \mathrm{~mL}$ sterile minimal medium (MIM) in $500 \mathrm{~mL}$ Erlenmeyer flasks containing $10 \mathrm{mM}(\mathrm{rac})-\alpha$-MBA, $100 \mathrm{mM}$ glycerol, $1 \mathrm{~g} / \mathrm{L} \mathrm{MgSO} 4.7 \mathrm{H}_{2} \mathrm{O}, 0.02 \mathrm{mg} / \mathrm{L} \mathrm{H}_{3} \mathrm{BO}_{3}, 0.2 \mathrm{mM} \mathrm{CaCl}, 0.1 \mathrm{mg} / \mathrm{L} \mathrm{MnSO}{ }_{4} .4 \mathrm{H}_{2} \mathrm{O}$, $0.1 \mathrm{mg} / \mathrm{L} \mathrm{CuSO}_{4} .5 \mathrm{H}_{2} \mathrm{O}, 0.1 \mathrm{mg} / \mathrm{L} \mathrm{NiSO}_{4} .6 \mathrm{H}_{2} \mathrm{O}, 2.0 \mathrm{mg} / \mathrm{L} \mathrm{NaMoO}_{4}, 0.05 \mathrm{mg} / \mathrm{L} \mathrm{CoCl}_{2}, 0.1 \mathrm{mg} / \mathrm{L} \mathrm{ZnCl}$, $4 \mathrm{mg} / \mathrm{L} \mathrm{FeSO}_{4} \cdot 7 \mathrm{H}_{2} \mathrm{O}$, and potassium phosphate buffer (50 mM, pH 7.0) [39]. $\mathrm{FeSO}_{4}$ and (rac)- $\alpha$-MBA were separately sterile filtrated and added to the medium. Autoclaving causes precipitation of ferric hydrate [40]. Each sample was prepared in duplicate. Enrichment went through two strategies:

In the first method, Erlenmeyer flasks were incubated for $24 \mathrm{~h}$ at $180 \mathrm{rpm}$ at $35^{\circ} \mathrm{C}$ (depending on the original temperature of the soil samples). After $24 \mathrm{~h}$ of incubation, a $100 \mu \mathrm{L}$ sample was transferred to $20 \mathrm{~mL}$ of fresh minimal medium and incubated for $24 \mathrm{~h}$ under the same conditions as described before. This serial dilution was repeated 3 times. After that, the culture was diluted with PBS buffer (10: $90 \mu \mathrm{L}$ ) and poured to MIM agar plates (mineral medium, $10 \mathrm{mM}(\mathrm{rac})-\alpha$-MBA with $1.5 \%$ agar) and incubated at $35^{\circ} \mathrm{C}$. As soon as colonies were visible, single colonies were streaked on new MIM agar plates to obtain uniform colonies under the same temperature.

In the second method, Erlenmeyer flasks were transferred to a dark place, without shaking, at $35^{\circ} \mathrm{C}$. During incubation, $1 \mathrm{~mL}$ of concentrated MIM (5X), $0.5 \%$ v $/ v$ glycerol, and $10 \mathrm{mM}(\mathrm{rac})-\alpha$-MBA were added to the flasks every week. After 3 months, the culture broth was centrifuged (1000 g, 2 min) and $100 \mu \mathrm{L}$ of supernatant was spread on MIM agar plates. The colonies were isolated after 3 days of incubation at $35^{\circ} \mathrm{C}$. This was continued until the isolation of single colonies was achieved.

\subsubsection{Selection of the Most Promising Strains}

To identify whether isolated strains use (rac)- $\alpha$-MBA as a sole nitrogen source or atmospheric nitrogen, o-Xylylenediamine was applied as a smart amino donor. Each colony was cultivated in a shake flask containing $20 \mathrm{~mL}$ MIM medium with $12 \mathrm{mM}(\mathrm{rac})-\alpha-\mathrm{MBA}$ for three days at $35^{\circ} \mathrm{C}$ at $120 \mathrm{rpm}$. The cells were harvested by centrifugation at $6000 \times \mathrm{g}$ for $10 \mathrm{~min}$ at $4{ }^{\circ} \mathrm{C}$ and resuspended in HEPES buffer ( $50 \mathrm{mM}, \mathrm{pH}$ 7.5). The cell concentration was adjusted to around $20 \mathrm{mg} / \mathrm{mL}$ by measuring dry cell mass based on Buß et al. [36]. The cells were frozen at $-80^{\circ} \mathrm{C}$ and thawed at room temperature for cell disruption.

Reaction was started by adding $50 \mu \mathrm{L}$ of whole cells to $150 \mu \mathrm{L}$ reaction solution containing $7.5 \mathrm{mM}$ o-Xylylenediamine, $5 \mathrm{mM}$ pyruvate, $1 \mathrm{mM}$ PLP, and 10\% DMSO in HEPES buffer (50 mM, pH 7.5) [41] in a 96-well plate. Each reaction was conducted in triplicate. The plate was incubated overnight at $35^{\circ} \mathrm{C}$, $150 \mathrm{rpm}$.

\subsubsection{Identification of Bacteria}

The positive strains were grown separately overnight in $\mathrm{LB}$ broth at $35^{\circ} \mathrm{C}, 150 \mathrm{rpm}$. DNA was extracted by ZR soil Microbe DNA Kit ${ }^{\mathrm{TM}}$. PCR was done with a Q5 high-fidelity PCR kit (NEB, 
Germany). Universal Primers (27F and 1492R) were applied to amplify $1.5 \mathrm{~kb} 16 \mathrm{~S}$ rDNA fragments. PCR was conducted following the manufacturer's instructions for Q5 polymerase. Gene sequencing was performed by Eurofins Company (Ebersberg, Germany). The resulting 16S rRNA gene sequences were compared with available gene sequences in the EZ bioCloud database [42].

\subsection{Enzymatic Properties and Substrate Specificity}

\subsubsection{Preparation of Crude Extract}

The inoculum $(3 \mathrm{~mL})$ was prepared by picking a single colony and cultivating it for three days in MIM with $12 \mathrm{mM}(\mathrm{rac})-\alpha$-MBA. The medium $(400 \mathrm{~mL})$ was inoculated by the addition of $1 \%(v / v)$ of the latter culture into $1 \mathrm{~L}$ shaking flasks containing MIM with $0.5 \mathrm{~g} / \mathrm{L}$ yeast extract and $12 \mathrm{mM}$ (rac)- $\alpha$-MBA overnight at $150 \mathrm{rpm}$ and $35^{\circ} \mathrm{C}$. Cells were harvested before reaching stationary phase by centrifugation at $6000 \times g$ for $10 \mathrm{~min}$ at $4{ }^{\circ} \mathrm{C}$. After washing the pellet with sodium phosphate buffer (50 mM, pH 7), cells were resuspended in $10 \mathrm{~mL}$ lysis buffer (sodium phosphate (50 mM, pH 7), $0.1 \mu \mathrm{M}$ $\mathrm{PLP}, 100 \mu \mathrm{g} / \mathrm{mL}$ lysozyme]. Afterwards, they were incubated for $1 \mathrm{~h}$ at room temperature, followed by sonification ( 3 cycles: 30 s pulse, $20 \mathrm{~s}$ pause; $60 \%$ amplitude) on ice. Subsequently, the cell debris was removed by centrifugation (20,000 rpm, $4{ }^{\circ} \mathrm{C}, 15 \mathrm{~min}$ ) in a JA-30-50 rotor (Coulter-Beckman centrifuge). The protein concentration of crude extract was determined by using the Roti ${ }^{\circledR}$-Quant universal kit (Carl Roth, Karlsruhe, Germany) following the manufacturer's instructions. Eventually, they were mixed with $15 \%$ glycerol and preserved in $-80^{\circ} \mathrm{C}$ for further analysis.

\subsubsection{Effect of Temperature, $\mathrm{pH}$, and Co-Solvent}

The effects of temperature and $\mathrm{pH}$ on enzyme activity were examined at different temperatures (25-65 ${ }^{\circ} \mathrm{C}$ at $\left.\mathrm{pH} 7\right)$ and various $\mathrm{pHs}\left(3-12\right.$ at $\left.35^{\circ} \mathrm{C}\right)$ by using Britton-Robinson buffer $\left(0.04 \mathrm{M} \mathrm{H}_{3} \mathrm{BO}_{3}\right.$, $\left.0.04 \mathrm{M} \mathrm{H}_{3} \mathrm{PO}_{4}, 0.04 \mathrm{M} \mathrm{CH}_{3} \mathrm{COOH}\right)$ containing an amino donor $(10 \mathrm{mM})$, amino acceptor $(10 \mathrm{mM})$, PLP $(0.1 \mathrm{mM})$, and DMSO $(10 \%)$. The total reaction volume was set to $0.25 \mathrm{~mL}$. The reactions were initiated by adding crude extract of enzyme $(\sim 1 \mathrm{mg} / \mathrm{mL})$.

To study the effect of solvent on $\omega$-TA activity, reactions were carried out applying various organic solvents with $0-20 \%(v / v)$ (for DMSO $0-40 \%)$. (rac)- $\alpha$-MBA $(10 \mathrm{mM})$ was used as amino donor and pyruvate $(10 \mathrm{mM})$ as amino acceptor in the presence of PLP $(0.1 \mathrm{mM})$ and cell-free extract $(\sim 1 \mathrm{mg} / \mathrm{mL})$. The reactions were carried out in Britton-Robinson buffer ( $\mathrm{pH} 7)$ at $35^{\circ} \mathrm{C}$ as described above.

Each reaction was conducted in triplicate and incubated (ThermoMixer, Eppendorf) at $600 \mathrm{rpm}$ for $1 \mathrm{~h}$. As a control, the reaction was conducted without adding enzyme. Furthermore, the amount of acetophenone in crude extract of enzyme was also evaluated. Reactions were stopped by heating to $95{ }^{\circ} \mathrm{C}$ for $5 \mathrm{~min}$. After centrifugation, the supernatant was analyzed by HPLC to detect produced acetophenone according to Section 3.4. Results are shown as relative activity.

\subsubsection{Substrate Specificity and Enantioselectivity}

The reactions were carried out according to Section 3.3.2. Various amino donors (10 mM) listed in Table 1 were tested using sodium pyruvate $(10 \mathrm{mM})$ as amino acceptor in the Britton-Robinson buffer $(\mathrm{pH} 7)$ and $15 \%(v / v)$ DMSO. The reaction was carried out at $35^{\circ} \mathrm{C}, 600 \mathrm{rpm}$, for $20 \mathrm{~h}$ (ThermoMixer, Eppendorf). The produced alanine was analyzed by HPLC according to Section 3.4.

Different amino acceptors $(10 \mathrm{mM})$ were tested with (S)- $\alpha$-MBA as amino donor $(10 \mathrm{mM})$ in Britton-Robinson buffer, $\mathrm{pH} \mathrm{7}$, at $35^{\circ} \mathrm{C}, 600 \mathrm{rpm}$, for $20 \mathrm{~h}$. The production of acetophenone was analyzed by HPLC according to Section 3.4 .

Each reaction was conducted in triplicate, and the average of three independent reactions was used for evaluation. Enzyme inactivation was applied by heating to $95^{\circ} \mathrm{C}$ for $5 \mathrm{~min}$. The supernatant was used for analysis after centrifugation. In addition, the amounts of alanine and acetophenone were measured in enzyme crude extracts as blanks. 


\subsection{HPLC Analytics}

All samples were analyzed by Agilent 1100 series HPLC system (Santa Clara, CA, USA). For the analysis of alanine, derivatization by using ortho-phthalaldehyde was carried out according to Brucher et al. [43] and Buß et al. [44], with an automated precolumn derivatization. A reversed-phase $\mathrm{C}_{18}$ column $(150 \times 4.6 \mathrm{~mm}$ HyperClone $5 \mu \mathrm{m}$ ODS, Phenomenex, Germany) with isocratic elution with $35 \%(v / v)$ methanol and $65 \%(v / v)$ sodium phosphate buffer $(40 \mathrm{mM}, \mathrm{pH} 6.5)$ at a flow rate of $0.8 \mathrm{~mL} \mathrm{~min}{ }^{-1}$ and detection at $338 \mathrm{~nm}$ at $25^{\circ} \mathrm{C}$ was used.

The acetophenone concentration in the samples was determined chromatographically by isocratic

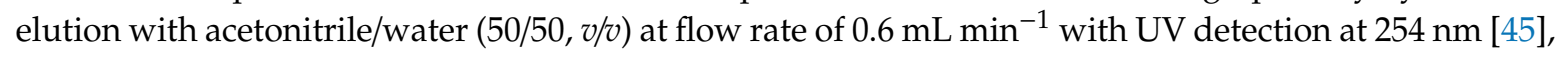
at $25^{\circ} \mathrm{C}$ applying a $\mathrm{C}_{18}$ Hypersil-keystone column $(250 \times 4.6 \mathrm{~mm} 5 \mu$ Hypersil). The injection volume was adjusted to $1 \mu \mathrm{L}$.

\section{Conclusions}

Our motivation for screening novel microorganisms exhibiting transaminase activity resulted from several challenges for the industrial application of $\omega$-TAs, e.g., lacking activity at acidic $\mathrm{pH}$, high temperature, unnatural substrates, $(R)$-configured molecules, and elevated concentrations of organic solvents (needed due to low substrate solubility in aqueous systems). We succeeded in finding promising new strains from a high variety of Iranian soil samples by enrichment culture using (rac)- $\alpha$-methylbenzylamine ( $\alpha$-MBA) as a sole nitrogen source.

In particular, a Bacillus halotolerans $(\mathrm{BaH})$ strain was isolated from a petroleum refinery, exhibiting $\omega$-TA activity using a broad spectrum of amino donors over a $\mathrm{pH}$ range of 5-9 at elevated concentrations of DMSO and other organic solvents up to $30 \%(v / v)$. Two other strains isolated from an agricultural field (Bacillus endophyticus, BaE) and an oilfield (Bacillus subtilis, BaS) showed the highest $\omega$-TA activity against $\alpha$-MBA at $\mathrm{pH} 5$ with $70 \%$ remaining activity at $\mathrm{pH} 3(\mathrm{BaS})$, whereas $\omega$-TAs are usually described to prefer slightly alkaline conditions. The enzymes dedicated to these extraordinary activities will be purified and subjected to in-depth studies for application-technical characterization.

Supplementary Materials: The following are available online at http://www.mdpi.com/2073-4344/9/10/874/s1, Table S1: The Effect of temperature on the amination of pyruvate and (S)-MBA as amino donor using $1 \mathrm{mg} / \mathrm{mL}$ cell-free extracts of BaI strain. Reaction conditions are given in the method section. Formation of acetophenone was detected by HPLC at $254 \mathrm{~nm}$. Every reaction was conducted in three replicates.

Author Contributions: Conceptualization, J.F. and J.R., methodology, N.G.N., M.Z.M., and U.E., validation, J.R., M.M.H., and U.E., formal analysis, N.G.N., investigation, N.G.N., data curation, N.G.N., writing-original draft preparation, N.G.N., writing—review and editing, N.G.N., J.F., J.R., U.E., M.M.H., M.Z.M., and C.S., visualization, M.Z.M., supervision, J.F., J.R., and C.S., project administration, J.F.

Funding: This research received no external funding.

Acknowledgments: This study was financially supported by grant No: 970201 of the Biotechnology Development Council of the Islamic Republic of Iran. The publication of this article was funded by Karlsruhe Institute of Technology (Helmholtz).

Conflicts of Interest: The authors declare that there is no conflict of interest.

\section{References}

1. Gomm, A.; Lewis, W.; Green, A.P.; O’Reilly, E. A New Generation of Smart Amine Donors for Transaminase-Mediated Biotransformations. Chem. A Eur. J. 2016, 22, 12692-12695. [CrossRef]

2. Pawar, S.V.; Hallam, S.J.; Yadav, V.G. Metagenomic Discovery of a Novel Transaminase for Valorization of Monoaromatic Compounds. RSC Adv. 2018, 8, 22490-22497. [CrossRef]

3. Aleku, G.A.; France, S.P.; Man, H.; Mangas-Sanchez, J.; Montgomery, S.L.; Sharma, M.; Leipold, F.; Hussain, S.; Grogan, G.; Turner, N.J. A Reductive Aminase from Aspergillus Oryzae. Nat. Chem. 2017, 9, 961. [CrossRef]

4. Kim, G.H.; Jeon, H.; Khobragade, T.P.; Patil, M.D.; Sung, S.; Yoon, S.; Won, Y.; Choi, I.S.; Yun, H. Enzymatic Synthesis of Sitagliptin Intermediate Using a Novel $\omega$-Transaminase. Enzym. Microb. Technol. 2019, 120, 52-60. [CrossRef] 
5. Mathew, S.; Nadarajan, S.P.; Chung, T.; Park, H.H.; Yun, H. Biochemical Characterization of Thermostable $\omega$-Transaminase from Sphaerobacter Thermophilus and its Application for Producing Aromatic $\beta$-and $\gamma$-Amino Acids. Enzym. Microb. Technol. 2016, 87, 52-60. [CrossRef]

6. Haycock-Lewandowski, S.J.; Wilder, A.; Åhman, J. Development of a Bulk Enabling Route to Maraviroc (UK-427,857), a CCR-5 Receptor Antagonist. Org. Process. Res. Dev. 2008, 12, 1094-1103. [CrossRef]

7. Slomka, C.; Zhong, S.; Fellinger, A.; Engel, U.; Syldatk, C.; Bräse, S.; Rudat, J. Chemical Synthesis and Enzymatic, Stereoselective Hydrolysis of a Functionalized Dihydropyrimidine for the Synthesis of $\beta$-Amino Acids. AMB Express 2015, 5, 85. [CrossRef]

8. Weiner, B.; Szymański, W.; Janssen, D.B.; Minnaard, A.J.; Feringa, B.L. Recent Advances in the Catalytic Asymmetric Synthesis of $\beta$-Amino Acids. Chem. Soc. Rev. 2010, 39, 1656-1691. [CrossRef]

9. Turner, N.J.; Truppo, M.D. Biocatalytic Routes to Nonracemic Chiral Amines. In Chiral Amine Synthesis: Methods, Developments and Applications; Nugent, T.C., Ed.; Wiley-VCH: Weinheim, Germany, 2010; pp. 431-459.

10. Mathew, S.; Jeong, S.S.; Chung, T.; Lee, S.H.; Yun, H. Asymmetric Synthesis of Aaromatic $\beta$-Amino Acids Using $\omega$-Transaminase: Optimizing the Lipase Concentration to Obtain Thermodynamically Unstable $\beta$-Keto Acids. Biotechnol. J. 2016, 11, 185-190. [CrossRef]

11. Malik, M.S.; Park, E.S.; Shin, J.S. Features and Technical Applications of $\omega$-Transaminases. Appl. Microbiol. Biotechnol. 2012, 94, 1163-1171. [CrossRef]

12. Jiang, J.; Chen, X.; Feng, J.; Wu, Q.; Zhu, D. Substrate Profile of an $\omega$-Transaminase from Burkholderia Vietnamiensis and its Potential for the Production of Optically Pure Amines and Unnatural Amino Acids. J. Mol. Catal. B Enzym. 2014, 100, 32-39. [CrossRef]

13. Cerioli, L.; Planchestainer, M.; Cassidy, J.; Tessaro, D.; Paradisi, F. Characterization of a Novel Amine Transaminase from Halomonas Elongata. J. Mol. Catal. B Enzym. 2015, 120, 141-150. [CrossRef]

14. Voss, M.; Das, D.; Genz, M.; Kumar, A.; Kulkarni, N.; Kustosz, J.; Kumar, P.; Bornscheuer, U.T.; Höhne, M. In Silico Based Engineering Approach to Improve Transaminases for the Conversion of Bulky Substrates. ACS Catal. 2018, 8, 11524-11533. [CrossRef]

15. Rudat, J.; Brucher, B.R.; Syldatk, C. Transaminases for the Synthesis of Enantiopure Beta-Amino Acids. $A M B$ Express 2012, 2, 11. [CrossRef]

16. Pavlidis, I.V.; Weiß, M.S.; Genz, M.; Spurr, P.; Hanlon, S.P.; Wirz, B.; Iding, H.; Bornscheuer, U.T. Identification of (S)-Selective Transaminases for the Asymmetric Synthesis of Bulky Chiral Amines. Nat. Chem. 2016, 8, 1076-1082. [CrossRef]

17. Kelly, S.A.; Magill, D.J.; Megaw, J.; Skvortsov, T.; Allers, T.; McGrath, J.W.; Allen, C.C.; Moody, T.S.; Gilmore, B.F. Characterisation of a Solvent-Tolerant Haloarchaeal (R)-Selective Transaminase Isolated from a Triassic Period Salt Mine. Appl. Microbiol. Biotechnol. 2019, 103, 5727-5737. [CrossRef]

18. Leipold, L.; Dobrijevic, D.; Jeffries, J.W.; Bawn, M.; Moody, T.S.; Ward, J.M.; Hailes, H.C. The Identification and Use of Robust Transaminases from a Domestic Drain Metagenome. Green Chem. 2019, 21, 75-86. [CrossRef]

19. Ferrandi, E.E.; Previdi, A.; Bassanini, I.; Riva, S.; Peng, X.; Monti, D. Novel Thermostable Amine Transferases from Hot Spring Metagenomes. Appl. Microbiol. Biotechnol. 2017, 101, 4963-4979. [CrossRef]

20. Genz, M.; Vickers, C.; van den Bergh, T.; Joosten, H.-J.; Dörr, M.; Höhne, M.; Bornscheuer, U. Alteration of the Donor/Acceptor Spectrum of the (S)-Amine Transaminase from Vibrio Fluvialis. Int. J. Mol. Sci. 2015, 16, 26953-26963. [CrossRef]

21. Kelly, S.A.; Megaw, J.; Caswell, J.; Scott, C.J.; Allen, C.C.; Moody, T.S.; Gilmore, B.F. Isolation and Characterisation of a Halotolerant $\omega$-Transaminase from a Triassic Period Salt Mine and Its Application to Biocatalysis. ChemistrySelect 2017, 2, 9783-9791. [CrossRef]

22. Shin, J.S.; Kim, B.G. Kinetic Resolution of $\alpha$-Methylbenzylamine with o-Transaminase Screened from Soil Microorganisms: Application of a Biphasic System to Overcome Product Inhibition. Biotechnol. Bioeng. 1997, 55, 348-358. [CrossRef]

23. Pavkov-Keller, T.; Strohmeier, G.A.; Diepold, M.; Peeters, W.; Smeets, N.; Schürmann, M.; Gruber, K.; Schwab, H.; Steiner, K. Discovery and Structural Characterisation of New Fold Type IV-Transaminases Exemplify the Diversity of This Eenzyme Fold. Sci. Rep. 2016, 6, 38183. [CrossRef] [PubMed]

24. Yazdi, A.; Emami, M.H.; Shafiee, S.M. Dasht-E Lut in Iran, the Most Complete Collection of Beautiful Geomorphological Phenomena of Desert. Open J. Geol. 2014, 4, 249-261. [CrossRef]

25. Ataee, N.; Fooladi, J.; Namaei, M.H.; Rezadoost, H.; Mirzajani, F. Biocatalysts Screening of Papaver Bracteatum Flora for Thebaine Transformation to Codeine and Morphine. Biocatal. Agric. Biotechnol. 2017, 9, 127-133. [CrossRef] 
26. Ghasemi, Y.; Rasoul-Amini, S.; Ebrahiminezhad, A.; Kazemi, A.; Shahbazi, M.; Talebnia, N. Screening and Isolation of Extracellular Protease Producing Bacteria from the Maharloo Salt Lake. Iran. J. Pharm. Sci. 2011, 7, 175-180.

27. Alghabpoor, S.S.; Panosyan, H.; Trchounian, A.; Popov, Y. Purification and Characterization of a Novel Thermostable and Acid Stable $\alpha$-Amylase from Bacillus Sp. Iranian S1. Int. J. Eng. Trans. B Appl. 2013, 26, 815-820. [CrossRef]

28. Shirsalimian, M.; Amoozegar, M.; Sepahy, A.A.; Kalantar, S.; Dabbagh, R. Isolation of Extremely Halophilic Archaea from a Saline River in the Lut Desert of Iran, Moderately Resistant to Desiccation and Gamma Radiation. Microbiology 2017, 86, 403-411. [CrossRef]

29. Shin, J.S.; Kim, B.G. Comparison of the $\omega$-Transaminases from Different Microorganisms and Application to Production of Chiral Amines. Biosci. Biotechnol. Biochem. 2001, 65, 1782-1788. [CrossRef]

30. Mathew, S.; Bea, H.; Nadarajan, S.P.; Chung, T.; Yun, H. Production of Chiral $\beta$-Amino Acids Using $\omega$-Transaminase from Burkholderia Graminis. J. Biotechnol. 2015, 196, 1-8. [CrossRef]

31. Guo, F.; Berglund, P. Transaminase Biocatalysis: Optimization and Application. Green Chem. 2017, 19, 333-360. [CrossRef]

32. Dreßen, A.; Hilberath, T.; Mackfeld, U.; Billmeier, A.; Rudat, J.; Pohl, M. Phenylalanine Ammonia Lyase from Arabidopsis Thaliana (AtPAL2): A Potent MIO-Enzyme for the Synthesis of Non-Canonical Aromatic Alpha-Amino Acids: Part I: Comparative Characterization to the Enzymes from Petroselinum Crispum (PcPAL1) and Rhodosporidium Toruloides (RtPAL). J. Biotechnol. 2017, 258, 148-157.

33. Schätzle, S.; Höhne, M.; Robins, K.; Bornscheuer, U.T. Conductometric Method for the Rapid Characterization of the Substrate Specificity of Amine-Transaminases. Anal. Chem. 2010, 82, 2082-2086. [CrossRef]

34. Schätzle, S.; Höhne, M.; Redestad, E.; Robins, K.; Bornscheuer, U.T. Rapid and Sensitive Kinetic Assay for Characterization of $\omega$-Transaminases. Anal. Chem. 2009, 81, 8244-8248. [CrossRef] [PubMed]

35. Koszelewski, D.; Tauber, K.; Faber, K.; Kroutil, W. $\omega$-Transaminases for the Synthesis of Non-Racemic $\alpha$-Chiral Primary Amines. Trends Biotechnol. 2010, 28, 324-332. [CrossRef] [PubMed]

36. Buß, O.; Dold, S.M.; Obermeier, P.; Litty, D.; Muller, D.; Grüninger, J.; Rudat, J. Enantiomer Discrimination in $\beta$-Phenylalanine Degradation by a Newly Isolated Paraburkholderia Strain BS115 and Type Strain PsJN. AMB Express 2018, 8, 149. [CrossRef] [PubMed]

37. Conti, E.; Stachelhaus, T.; Marahiel, M.A.; Brick, P. Structural Basis for the Activation of Phenylalanine in the Non-Ribosomal Biosynthesis of Gramicidin S. EMBO J. 1997, 16, 4174-4183. [CrossRef] [PubMed]

38. Yamada, M.; Kurahashi, K. Further Purification and Properties of Adenosine Triphosphate-Dependent Phenylalanine Racemase of Bacillus Brevis Nagano. J. Biochem. 1969, 66, 529-540. [CrossRef]

39. Yun, H.; Lim, S.; Cho, B.K.; Kim, B.G. w-Amino Acid: Pyruvate Transaminase from Alcaligenes Denitrificans Y2k-2: A New Catalyst for Kinetic Resolution of $\beta$-Amino Acids and Amines. Appl. Environ. Microbiol. 2004, 70, 2529-2534. [CrossRef]

40. Temple, K.L.; Colmer, A.R. The Autotrophic Oxidation of Iron by a New Bacterium: Thiobacillus Ferrooxidans. J. Bacteriol. 1951, 62, 605.

41. Buß, O.; Voss, M.; Delavault, A.; Gorenflo, P.; Syldatk, C.; Bornscheuer, U.; Rudat, J. $\beta$-Phenylalanine Ester Synthesis from Stable $\beta$-Keto Ester Substrate Using Engineered $\omega$-Transaminases. Molecules 2018, 23, 1211. [CrossRef]

42. Yoon, S.H.; Ha, S.M.; Kwon, S.; Lim, J.; Kim, Y.; Seo, H.; Chun, J. Introducing EzBioCloud: A taxonomically united database of $16 \mathrm{~S}$ rRNA gene sequences and whole-genome assemblies. Int. J. Syst. Evol. Microbiol. 2017, 67, 1613. [PubMed]

43. Brucher, B.; Rudat, J.; Syldatk, C.; Vielhauer, O. Enantioseparation of Aromatic $\beta^{3}$-Amino Acid by Precolumn Derivatization with o-Phthaldialdehyde and N-Isobutyryl-1-Cysteine. Chromatographia 2010, 71, 1063-1067. [CrossRef]

44. Buß, O.; Muller, D.; Jager, S.; Rudat, J.; Rabe, K.S. Improvement in the Thermostability of a $\beta$-Amino Acid Converting $\omega$-Transaminase by Using FoldX. ChemBioChem 2018, 19, 379-387. [CrossRef] [PubMed]

45. Gao, S.; Su, Y.; Zhao, L.; Li, G.; Zheng, G. Characterization of a (R)-Selective Amine Transaminase from Fusarium Oxysporum. Process Biochem. 2017, 63, 130-136. [CrossRef]

(C) 2019 by the authors. Licensee MDPI, Basel, Switzerland. This article is an open access article distributed under the terms and conditions of the Creative Commons Attribution (CC BY) license (http://creativecommons.org/licenses/by/4.0/). 